\title{
AN OVERVIEW OF EXPERIMENTAL EFFORTS TO UNDERSTAND THE MECHANISMS OF FISH INJURY AND MORTALITY CAUSED BY HYDROPOWER TURBINE BLADE STRIKE
}

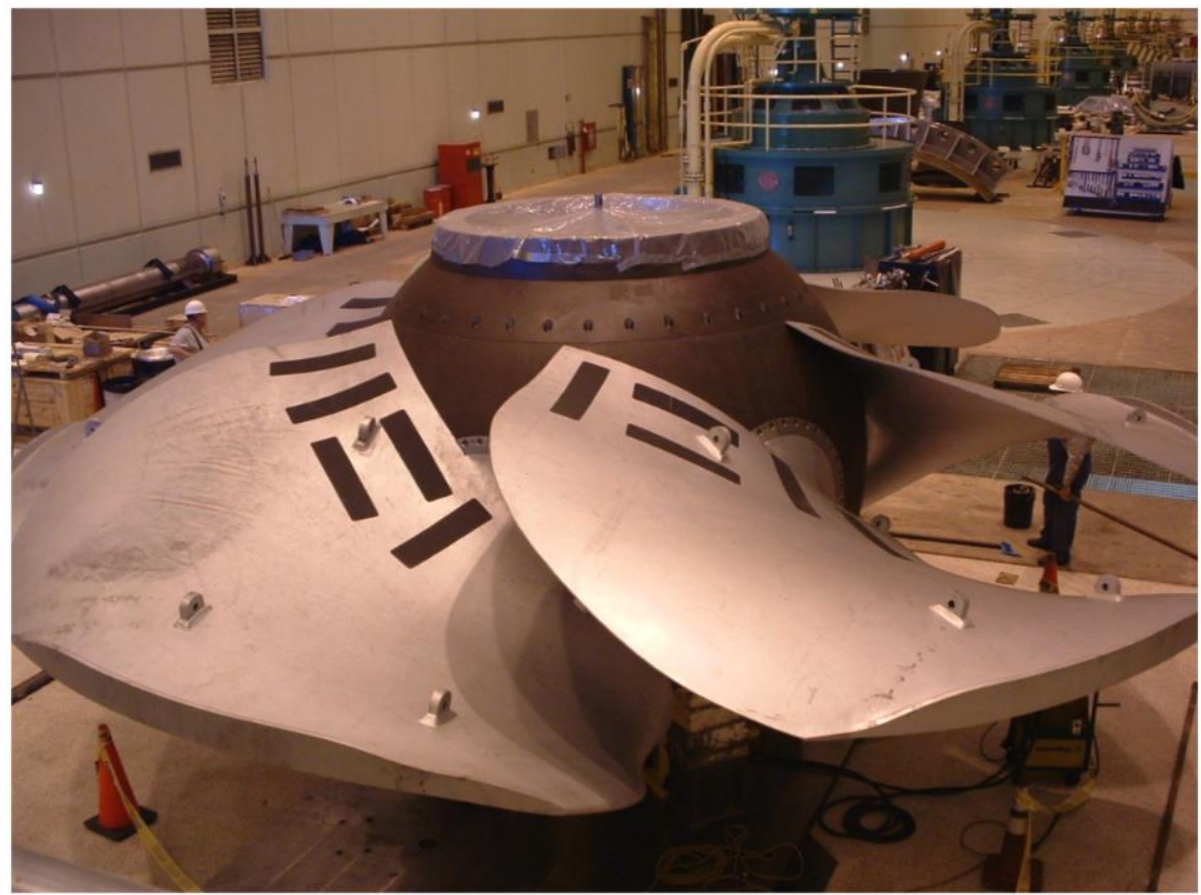

Approved for public release. Distribution is unlimited.
M. S. Bevelhimer

B. M. Pracheil

A. M. Fortner

K. L. Deck

December 2017 


\section{DOCUMENT AVAILABILITY}

Reports produced after January 1, 1996, are generally available free via US Department of Energy (DOE) SciTech Connect.

Website http://www.osti.gov/scitech/

Reports produced before January 1, 1996, may be purchased by members of the public from the following source:

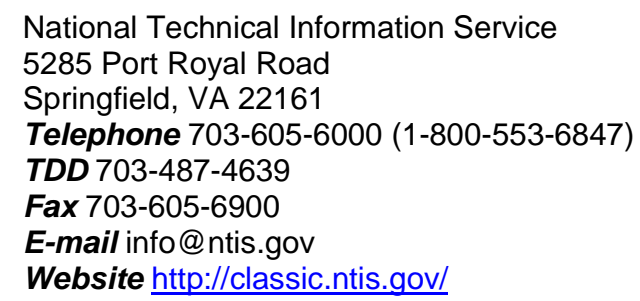

Reports are available to DOE employees, DOE contractors, Energy Technology Data Exchange representatives, and International Nuclear Information System representatives from the following source:

Office of Scientific and Technical Information

PO Box 62

Oak Ridge, TN 37831

Telephone 865-576-8401

Fax 865-576-5728

E-mail reports@osti.gov

Website http://www.osti.gov/contact.html

This report was prepared as an account of work sponsored by an agency of the United States Government. Neither the United States Government nor any agency thereof, nor any of their employees, makes any warranty, express or implied, or assumes any legal liability or responsibility for the accuracy, completeness, or usefulness of any information, apparatus, product, or process disclosed, or represents that its use would not infringe privately owned rights. Reference herein to any specific commercial product, process, or service by trade name, trademark, manufacturer, or otherwise, does not necessarily constitute or imply its endorsement, recommendation, or favoring by the United States Government or any agency thereof. The views and opinions of authors expressed herein do not necessarily state or reflect those of the United States Government or any agency thereof. 
Environmental Sciences Division

\title{
AN OVERVIEW OF EXPERIMENTAL EFFORTS TO UNDERSTAND THE MECHANISMS OF FISH INJURY AND MORTALITY CAUSED BY HYDROPOWER TURBINE BLADE STRIKE
}

\author{
M. S. Bevelhimer \\ B. M. Pracheil \\ A. M. Fortner \\ K. L. Deck
}

December 2017

\author{
Prepared by \\ OAK RIDGE NATIONAL LABORATORY \\ Oak Ridge, TN 37831-6283 \\ managed by \\ UT-BATTELLE, LLC \\ for the \\ US DEPARTMENT OF ENERGY \\ under contract DE-AC05-00OR22725
}





\section{CONTENTS}

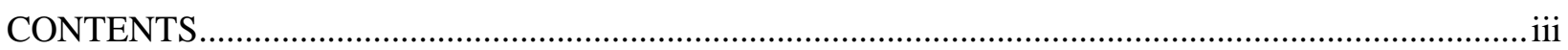

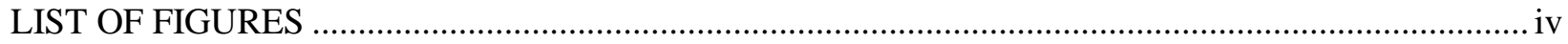

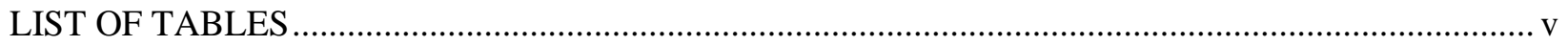

ACRONYMS …

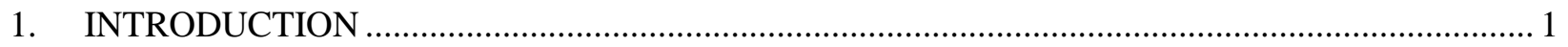

2. GENERAL OVERVIEW OF STRIKE STUDIES REVIEWED …............................................. 2

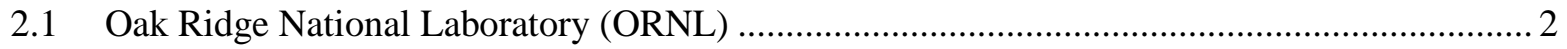

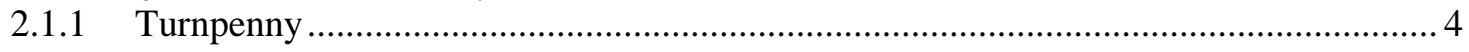

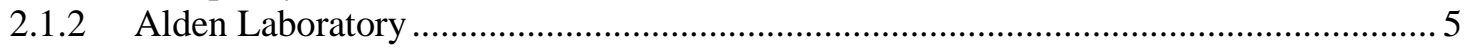

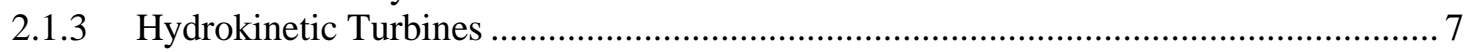

2.1.4 Screw Pumps (Archimedes, hidrostal, etc.) ......................................................... 7

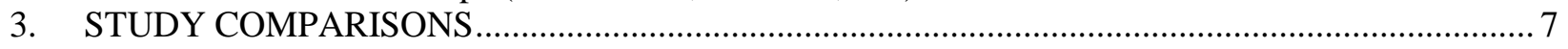

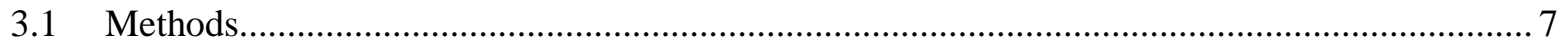

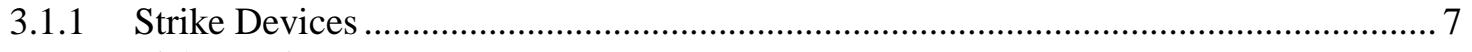

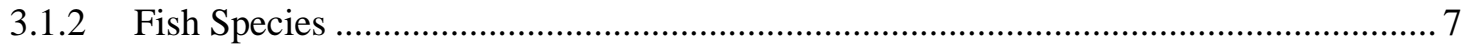

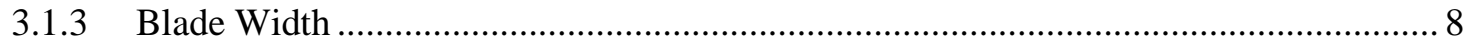

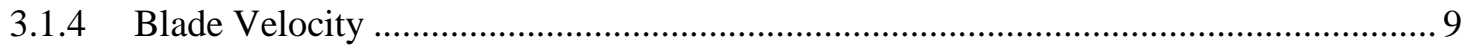

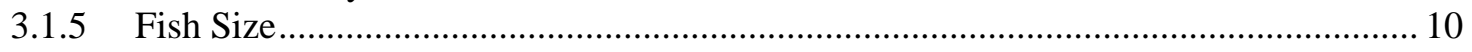

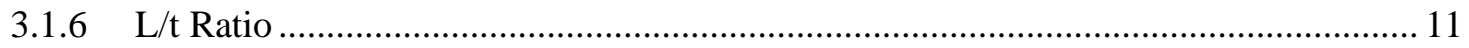

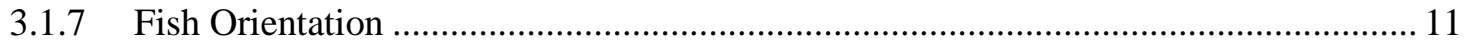

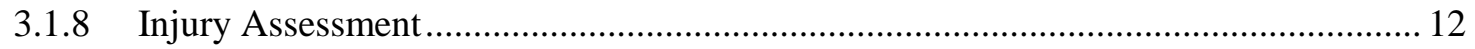

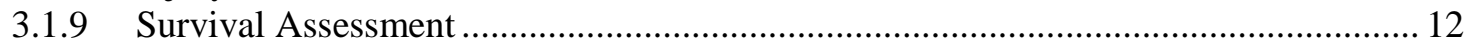

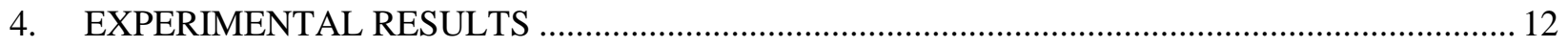

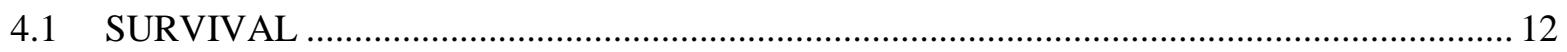

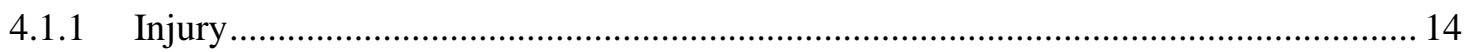

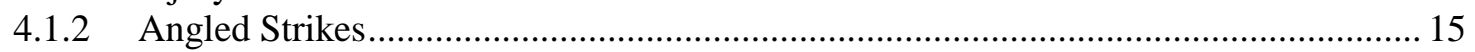

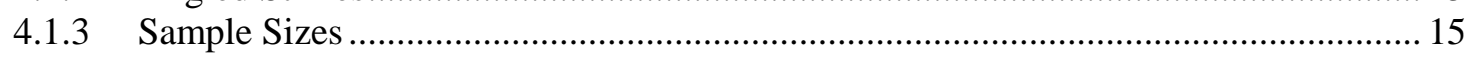

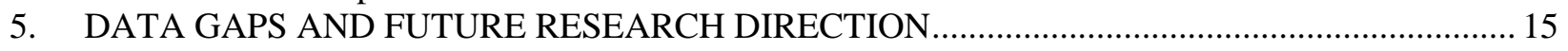

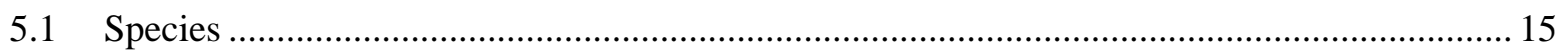

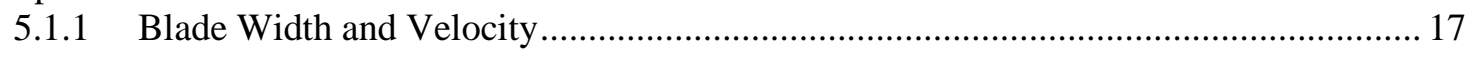

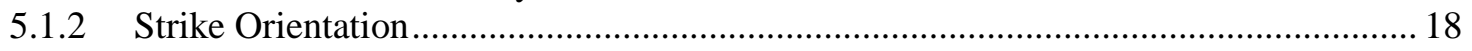

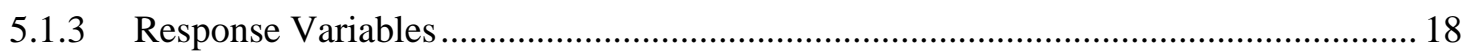

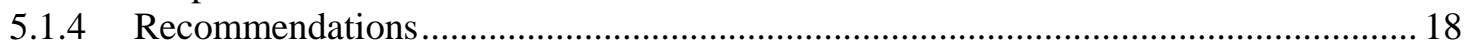

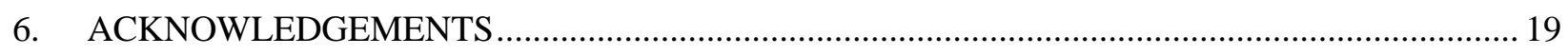

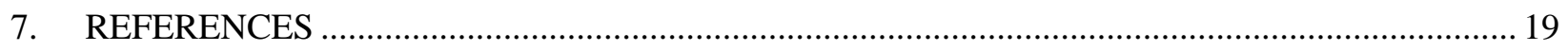




\section{LIST OF FIGURES}

Figure 1. Drawing of spring-powered blade strike simulator. Tank dimensions are $0.9 \mathrm{~m}$ length $\mathrm{X} 0.6 \mathrm{~m}$ width $\mathrm{X} 0.6 \mathrm{~m}$ height.

Figure 2. Strike platform with model fish held in place with flexible rubber tubing. 26-mm blade in the photo is positioned where it would be right before striking the fish.

Figure 3. Body locations and strike angles tested in ORNL studies in 2016 and 2017. Arrows indicate direction of blade path.

Figure 4. Diagram showing the spring-powered blade-strike apparatus used in the Turnpenny studies: (a) the main tank assembly; and (b) the fish/blade geometry. (Source: Turnpenny 1998)

Figure 5. Alden Laboratory's linear blade strike test tank. (Source: EPRI 2008)

Figure 6. Leading edge blade widths $(\mathrm{mm})$ tested in ORNL, Alden, and Turnpenny studies ordered left to right by research group, study or report year, and species.

Figure 7. Blade velocities (m/s) tested in ORNL, Alden, and Turnpenny studies ordered by report year and species.

Figure 8. Minimum, maximum, and mean lengths $(\mathrm{mm})$ of fish tested in ORNL, Alden, and Turnpenny studies ordered by report year and species.

Figure 9. Fish length to blade width ratios (L/t) tested in ORNL, Alden, and Turnpenny studies ordered by report year and species.

Figure 10. One-hour survival results of ORNL 2016 strike treatments (species by blade width by strike location).

Figure 11. This base figure (in gray scale) summarizes the results of rainbow trout strike studies conducted at Alden Laboratories and reported in EPRI (2011). 


\section{LIST OF TABLES}

Table 1. Species used in blade strike studies reported in ORNL, Turnpenny, and Alden studies............... 8

Table 2. Summary of current priority species and life stages for the BioDE dose-response studies.

(Source BioDE MYRP 2017) 16 


\section{ACRONYMS}

$\begin{array}{ll}\text { BioDE } & \text { Biologically-based Design and Evaluation } \\ \text { BioPA } & \text { Biological Performance Assessment } \\ \text { CFD } & \text { Computational Fluid Dynamics } \\ \text { EPRI } & \text { Electric Power Research Institute } \\ \text { ORNL } & \text { Oak Ridge National Laboratory }\end{array}$




\section{INTRODUCTION}

Injury and mortality of fish during downstream passage through hydropower turbines is one of the most significant concerns with regards to hydropower impacts on fish. Downstream turbine passage has the potential to be detrimental to fish due to a complex suite of stressors that are experienced as fish pass through a turbine, which can lead to injury and/or mortality. These stressors include rapid pressure changes, shear forces, mechanical strike from turbine runners, and collisions with turbine housing (Pracheil et al. 2016a). Hydropower owners/operators are frequently ordered to mitigate this threat through various means, such as installing racks or bypass systems that exclude fish from turbines or temporarily suspending generation by spilling water instead of routing it through turbines during periods of fish migration. These measures typically result in increased construction and operation costs or lost generation revenue (Schramm et al. 2016).

Injuries from blade strike (i.e., contact with turbine runners) range from minor (e.g., descaling or bruising) to severe (e.g., lacerations, organ damage, and broken bones) and can result in immediate or latent mortality. Turbine type, runner design, and operation, and other biological and runner blade geometry factors determine the severity and the likelihood of strike. In addition, fish may collide with stationary structures such as stay vanes and wicket gates prior to encountering the spinning turbine runner. Due to high water velocity and extreme turbulence within the turbine environment that exceed the swimming capacity of most species, it is unlikely that fish are able to actively avoid turbine strike by making evasive movements. Fish physiology, physiological state, and size, in addition to turbine design and operation, are important factors influencing the likelihood and severity of strike which can lead to injuries ranging from slight to lethal (Čada 2001). For some turbine types the position of the fish relative to the runner blades at runner entry influences the likelihood and severity of strike (Bevelhimer et al. in preparation). Fish struck at the leading edge may also have high likelihood of subsequent barotrauma injuries if they then pass along the suction side of runner blades. Minor injuries typically include disorientation, scale loss, bruising, and stunning, while major injuries include lacerations, broken bones, ruptured swim bladders, and organ damage.

Because the impacts of blade strike on fish vary among species, size of fish, turbine design, and operating conditions, a better understanding of the complex relationships among these factors and fish injury and mortality could be used to improve turbine designs to reduce such impacts. For example, turbine manufacturers already consider thicker leading edges on runner blades as a result of laboratory studies that showed a direct relationship between blade thickness and injury (Turnpenny 1992, EPRI 2008). Similarly, the realization that space between a turbine blade and the turbine hub and wall causes pinching injuries resulted in minimum gap runner designs that significantly reduced that source of injury (Čada 2001). Efforts to capture the importance of these variables in assessing and predicting the likelihood and severity of the impacts of blade strike have come in the form of (1) computational models that predict the probability of blade strike (Deng et al. 2011; Richmond et al. 2014), (2) release of live fish into operating turbines followed by recapture and injury assessment (Mathur et al. 1996, 2000), and (3) laboratory studies of simulated blade strike (Turnpenny 1992; EPRI 2008, 2011a; present studies at Oak Ridge National Laboratory [ORNL]). The computational models (both Computational Fluid Dynamic models and probabilistic models) predict the likelihood of encounter with turbine surfaces but by themselves are not able to predict level of injury or probability of mortality. Field fish passage studies have successfully quantified the types of injuries and the amount of mortality caused during passage at projects of different designs, but these studies, which cannot observe what is happening inside the turbine, are not able to relate what specific conditions within the turbine cause which observed injuries.

To better understand precisely which injuries are caused by which stressors, it is necessary to conduct highly controlled experiments that can quantify precise strike conditions and the resulting outcome (i.e., 
type and severity of injury and mortality). Experimentally-derived dose-response relationships are necessary to inform low-impact turbine designs via the Biological Performance Assessment (BioPA) modeling tool. The BioPA model predicts the probability of injury based on stressor exposure derived from computational fluid dynamics models and dose-response relationships determined in controlled laboratory studies. With that in mind, the goals of this report are to:

- summarize the experimental designs of blade strike studies carried out at ORNL in 2016 and 2017 relative to similar studies by other investigators, and

- describe a path forward for understanding the complex interactions among the key factors that affect the fate of fish that contact runners and other turbine structures during turbine passage.

Note that this report does not go into great detail on sample sizes, statistical analysis, or results interpretation as those items are complex due to the number of combinations of different factors being tested and because these details are included in the individual reports and peer-reviewed articles.

\section{GENERAL OVERVIEW OF STRIKE STUDIES REVIEWED}

We found reports of controlled blade strike studies at only two laboratories other than ORNL. An overview of the experiments conducted by these three research groups and of some related studies with hydrokinetic turbines and screw pumps is presented in this section.

\subsection{Oak Ridge National Laboratory (ORNL)}

Since 2016, blade strike studies have been conducted at ORNL using a spring-powered strike simulator (Figure 1). These tests included blade strike exposure doses that used various combinations of blade velocity $(6-9 \mathrm{~m} / \mathrm{s})$, blade leading edge width $(26$ and $52 \mathrm{~mm})$, strike location on the body (head, midsection, and tail; lateral, ventral, and dorsal), and strike angle (perpendicular and $45^{\circ}$ ) for three fish species. Each of these variables plays a significant role in the resulting response or impact.

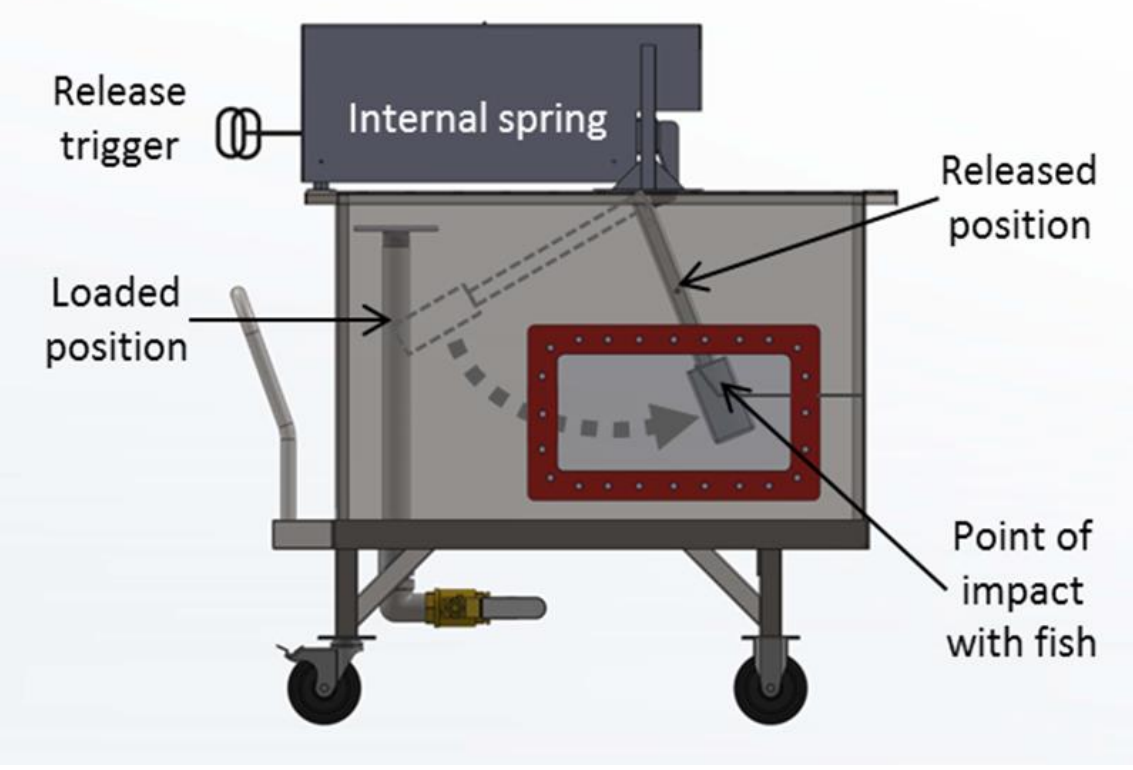

Figure 1. Drawing of spring-powered blade strike simulator. Tank dimensions are $0.9 \mathrm{~m}$ length $\mathrm{X} 0.6 \mathrm{~m}$ width X $0.6 \mathrm{~m}$ height. 
While four different blades with leading edge widths of 10, 20, 26, and $52 \mathrm{~mm}$ (with semi-circular leading edges) were on hand for attachment to the strike arm, only the two largest have been used in experiments to date. The two blade widths tested best match our priorities for blade width (i.e., more representative of turbine blades) and fish length: blade width ratios (i.e., in a range where there is most uncertainty about survival). Blade velocity can be varied by adjusting an internal bolt that changes the tension on the spring. Because the 52-mm blade has more resistance as it moves through the water, its range of velocity via tension adjustment alone $(7.3-8.2 \mathrm{~m} / \mathrm{s})$ is lower than that of the $26-\mathrm{mm}$ blade $(10.1-12.2 \mathrm{~m} / \mathrm{s})$.

Additional reduction in velocity was achieved for both blades by covering the arm holding the blade with plastic tubing to add more resistance, resulting in minimum velocities of approximately $7.3 \mathrm{and} 6.1 \mathrm{~m} / \mathrm{s}$ for the 26-mm and 52-mm blades, respectively.

Two 50-mm-wide adjustable platforms held anesthetized fish in the strike zone at an angle that resulted in a blade strike that was perpendicular to the side of the fish (Figure 2). Sections of rubber tubing ( $7 \mathrm{~mm}$ diameter, $7 \mathrm{~cm}$ length) secured at one end to the holding platforms lightly held fish in position with minimal resistance to provide repeatable strike conditions. Observation of high-speed video confirmed that the tubing provided virtually no resistance during the strike, and at impact fish were carried away from the platform either in the direction of the blade or off to either side if not struck in the midsection. To date, ORNL has conducted tests on three species - yearling rainbow trout Oncorhynchus mykiss, adult gizzard shad Dorosoma cepedianum, and yearling hybrid striped bass Morone saxatilus X M. chrysops.

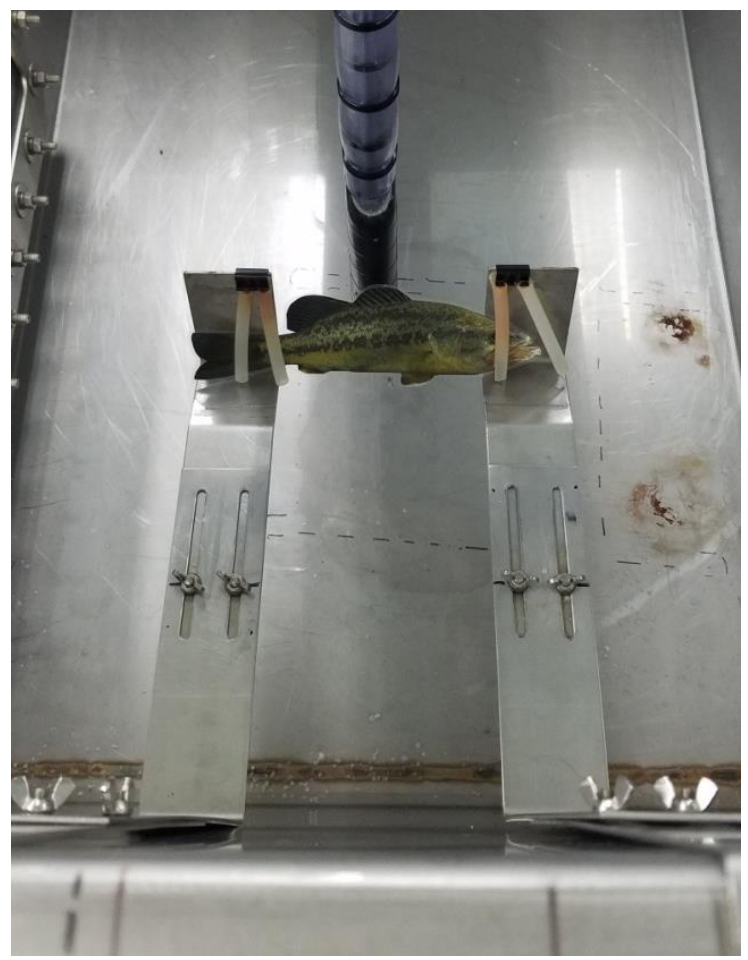

Figure 2. Strike platform with model fish held in place with flexible rubber tubing. 26-mm blade in the photo is positioned where it would be right before striking the fish.

Because the orientation of fish as they pass through a turbine is largely unknown, ORNL conducted blade strikes to a variety of body locations and at a variety of angles. Although the standard fish orientation on the strike platform is a lateral strike to the midsection, ORNL also conducted lateral strikes to the head 
and caudal (tail) regions. In addition, we conducted a series of trials with fish lying on its side on the strike platform to produce ventral (belly) and dorsal (back) strikes at the middle of the fish only.

Angled strikes were accomplished by adjusting the strike platform so that fish could be held at $45^{\circ}$ angles, both head-first and tail-first. Using the blade path as a reference, a fish facing directly into the blade would be designated as $0^{\circ}$ (head pointing towards 12:00 on a clock; not tested), a fish positioned at a right angle to the blade was designated as a $90^{\circ}$ strike (head pointing towards 3:00), a fish positioned at a $45^{\circ}$ angle and struck in the head to tail direction was designated as a $45^{\circ}$ strike (head pointing towards 1:30), and a fish positioned at a $45^{\circ}$ angle but struck in the tail to head direction was designated as a $225^{\circ}$ strike (head pointing towards 10:30) (Figure 3).
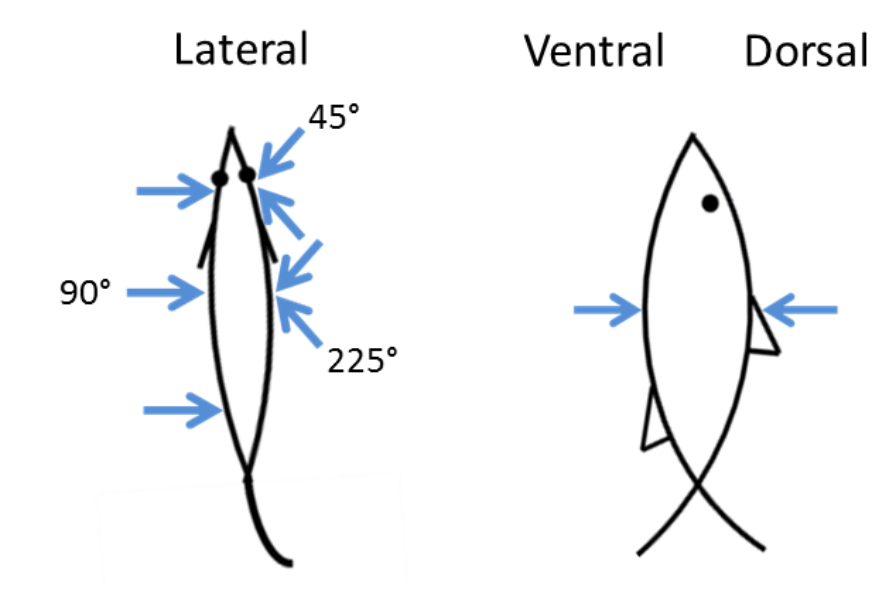

Figure 3. Body locations and strike angles tested in ORNL studies in 2016 and 2017. Arrows indicate direction of blade path.

After being struck, fish were photographed, tagged with an identification number in the lower jaw, and placed into a holding tank for observation for up to $1 \mathrm{hr}$. Fish that appeared dead (no body movement or gill beats) at any time during the hour and those with significant bleeding were placed in a euthanasia bath. Notes were made for each fish every 10-15 minutes as to its ability to swim normal and upright. Fish that could not maintain equilibrium or swim normally were considered as mortalities in the final analysis. All fish were held for at least $1 \mathrm{hr}$ for observation after strike (including controls that received the same treatment except for the actual strike) and a subset (about 20\% of samples in 2016) were held for an additional $47 \mathrm{hr}$ to assess latent mortality. Following euthanasia, whether after $1 \mathrm{hr}$ or $48 \mathrm{hr}$, all fish were evaluated for external and internal injuries. Visible external injuries assessed included bruising, hemorrhaging, eye injury, fin damage, spinal deformation, and descaling. Internal injuries that were assessed included sub-dermal contusions, hemorrhaging, broken bones and spines, and internal organ damage.

To date, ORNL studies included strike tests with three species in 2016 (rainbow trout, striped bass hybrid, and gizzard shad) and two species in 2017 (striped bass hybrids and gizzard shad). In 2016, all three species were subjected to head, mid-section, and tail strikes with two blade widths and mostly a single velocity. In 2017, each species was subjected to three velocities with a single blade width and fish orientation was expanded to include mid-section ventral and dorsal hits and lateral hits at $45^{\circ}$ and $225^{\circ}$.

\subsubsection{Turnpenny}

The earliest turbine blade strike studies we found were described in papers and reports by Turnpenny et al. $(1992,1998,2000)$. Throughout this report we often speak of these results collectively as 'Turnpenny 
studies' or by 'Turnpenny researchers'. These references are not in the primary literature and difficult to find; however, we were able to locate Turnpenny et al. (1998) which summarizes the studies conducted in the United Kingdom in the early and mid-1990's. In addition, Cook et al. (2003) provides a good summary of the Turnpenny experiments. The strike simulator used by Turnpenny used a spring-driven mechanism to carry a single blade into a suspended euthanized fish at velocities between 5.2 to $7.1 \mathrm{~m} / \mathrm{s}$ (Figure 4). Four different blades were used with widths that represented those from the runner tip (10 $\mathrm{mm})$ to the hub $(100 \mathrm{~mm})$ of a typical turbine and two widths in between. Each blade was tested at only a single velocity, the $10 \mathrm{~mm}$ blade at $7.1 \mathrm{~m} / \mathrm{s}$, the $100 \mathrm{~mm}$ blade at $5.2 \mathrm{~m} / \mathrm{s}$, and the two intermediate widths at 6.9 and $7.0 \mathrm{~m} / \mathrm{s}$. The velocities tested by Turnpenny were most similar to those closer to the hub than the blade tip of a large Kaplan turbine.

Fish were held in place with a fine thread that was released at the time of blade release. The intended orientation for all trials was a $90^{\circ}$ strike to the midsection. Video recordings were used to confirm the location and angle of strike if different than intended and whether the fish wrapped around the blade at impact or was deflected to the side. Injury and mortality were assessed with live fish: brown trout, European bass, and European eel; while strike impact analyses were conducted with freshly euthanized fish: brown trout Salmo trutta, European eel Anguilla anguilla, rainbow trout, sand smelt Atherina presbyter, Atlantic herring Clupea harengus, and European bass Dicentrarchus labrax. Survival was assessed immediately after strike and again at $168 \mathrm{hr}$. Survival rates were based only on those fish that were hit near enough to the center of the fish such that the fish wrapped around the blade when struck. Fish that were brushed to the side were not considered as having been struck.

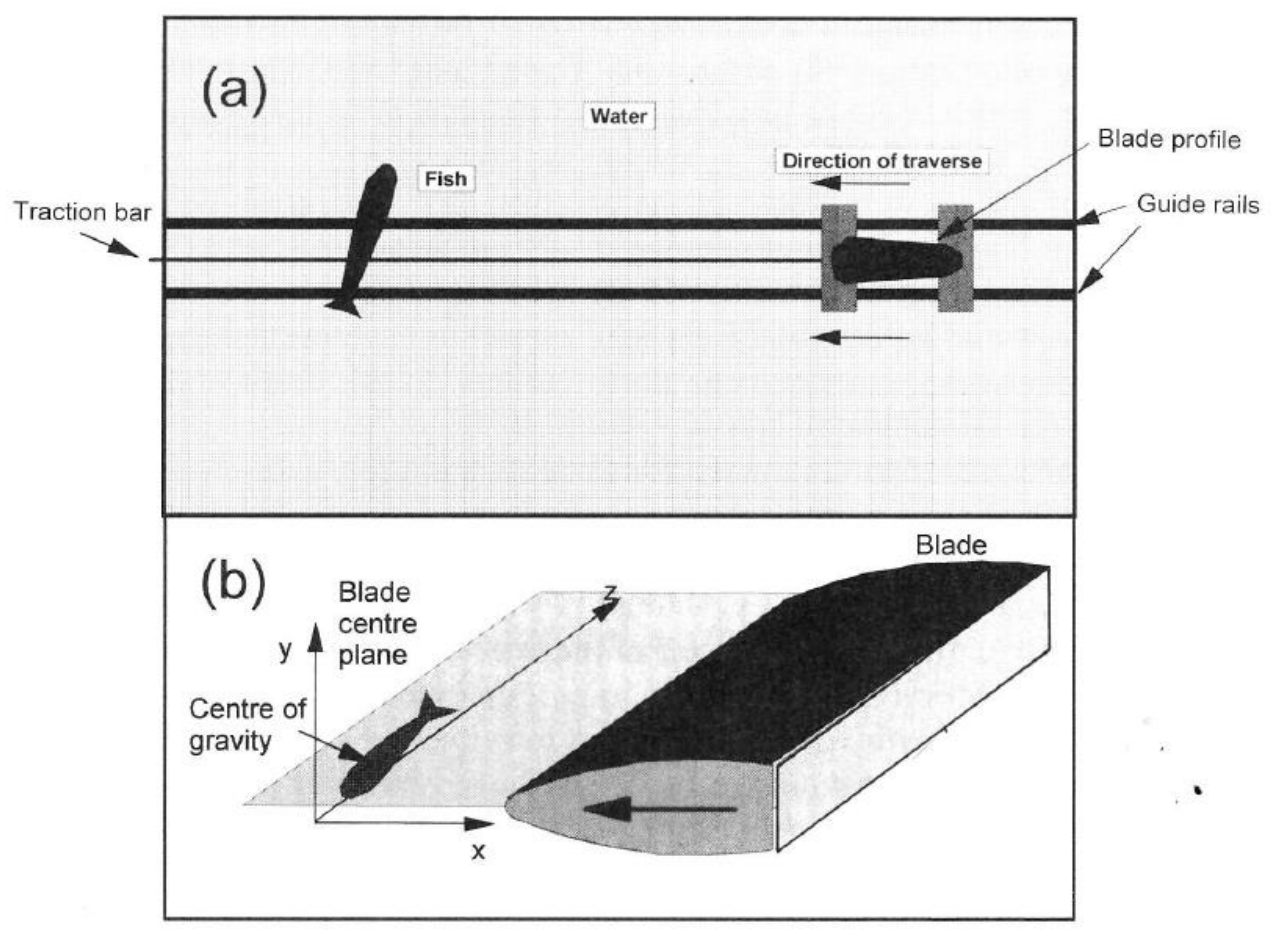

Figure 4. Diagram showing the spring-powered blade-strike apparatus used in the Turnpenny studies: (a) the main tank assembly; and (b) the fish/blade geometry. (Source: Turnpenny 1998)

\subsubsection{Alden Laboratory}


The only other set of laboratory strike studies designed specifically to test the impacts of conventional hydropower turbines on fish injury and survival were conducted at Alden Laboratories in Massachusetts and reported in a series of Electric Power Research Institute (EPRI) reports (EPRI 2008, 2011a, 2011b) and conference proceedings (Amaral et al. 2008, 2011). Throughout this report we often speak of these results collectively as 'Alden studies' or by 'Alden researchers'.

The Alden strike apparatus was a $16.5-\mathrm{m}$ long by $0.9-\mathrm{m}$ width and depth tank with a cable or chain-driven blade powered externally with a 20-horsepower electric motor (Figure 5). Magnetic sensors were used to measure the blade speed and to track the blade location. Six blade widths $(9.5,25,50,100$, and $150 \mathrm{~mm})$ were tested at a variety of velocities from 3.0 to $12.2 \mathrm{~m} / \mathrm{s}$.

Species tested included rainbow trout (mean lengths of treatment groups from 113 to $244 \mathrm{~mm}$ ), American eels Anguilla rostrate (mean group lengths from 285 to $789 \mathrm{~mm}$ ), and white sturgeon Acipenser transmontanus (mean group length from 106 to $158 \mathrm{~mm}$ ). Individual anesthetized fish were held in place with monofilament line in an orientation for most fish that was perpendicular to the blade path; a small subset of fish was subjected to $45^{\circ}$ strikes. Because the tethering mechanism allowed fish to rotate before being struck, whether the blade struck the fish laterally (on the side), ventrally, or dorsally, was not controlled, but was assessed and noted during post-processing of recorded high-speed video. After postprocessing, about 50-80\% of the fish were struck laterally with the rest either dorsal or ventral. Likewise, head and tail strikes were not targeted but after video analysis, about $20-25 \%$ of the strikes occurred at either the head or tail, with the other $75-80 \%$ at the midsection. After being struck, fish were immediately photographed, weighed and measured, and examined for external injury and then placed in a recovery tank. Visible external injuries assessed included bruising, hemorrhaging, eye injury, fin damage, spinal deformation, and descaling. Descaling was noted if $>20 \%$ scale loss occurred in two or more of the three body regions. Mortality was assessed at $1 \mathrm{hr}$ (immediate) and $96 \mathrm{hr}$.

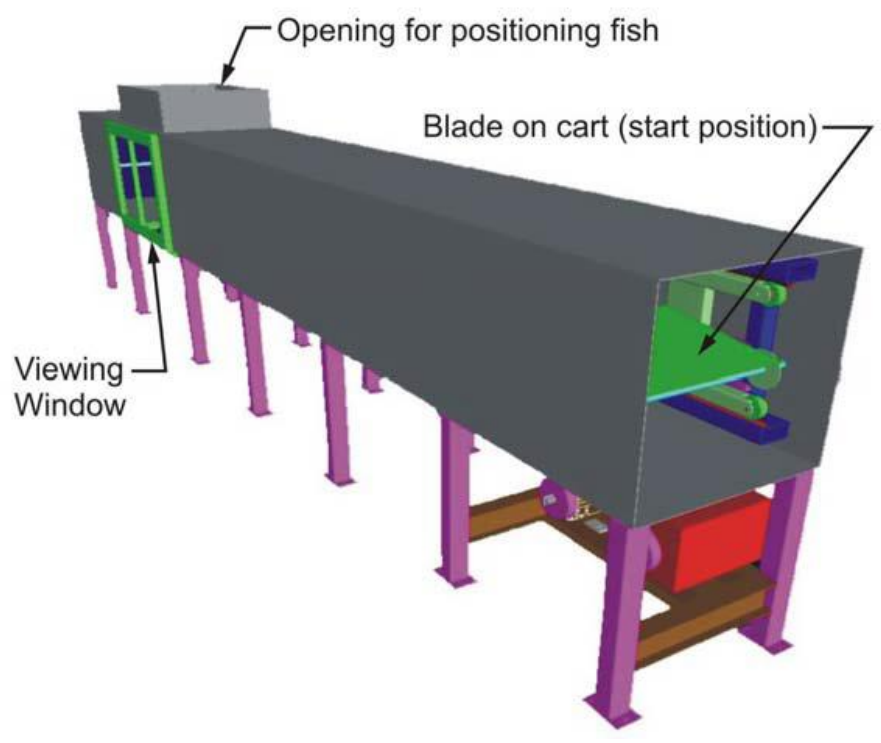

Figure 5. Alden Laboratory's linear blade strike test tank. (Source: EPRI 2008) 


\subsubsection{Hydrokinetic Turbines}

A number of laboratory studies have evaluated blade strike as fish passed 'volitionally' through hydrokinetic turbines of different designs (EPRI 2011a, 2011b, 2012, Amaral et al. 2015). These studies were conducted in flumes with live, non-anesthetized fish released individually or in groups to pass through the rotating turbine blades in a semi-natural way. Fish were not restrained but volitional movements were constrained by features of the experimental design that often offered no place to go but through the turbines, and turbine entrainment sometimes occurred as a result of loss of swimming endurance. These studies were conducted with adolescent and young adult fish, rainbow trout, largemouth bass Micropterus salmoides, Atlantic salmon Salmo salar, American shad Alosa sapidissima, hybrid striped bass, and white sturgeon. In a similar study, Schweizer et al. (2012) evaluated the survival of early life stages of fish after passing a fixed blade in flowing water in a laboratory setting. For all of these hydrokinetic turbine studies, group survival rates were quantified, but because blade contact was not specifically induced, survival and injury could not be associated with blade contact by individual fish. Therefore, the results of these studies are not comparable to the directed blade strike studies of ORNL, Turnpenny, and Alden, and will not be considered further in this analysis.

\subsubsection{Screw Pumps (Archimedes, hidrostal, etc.)}

Several studies have evaluated the effects of passage though different designs of screw pumps, e.g., Archimedes screws, hidrostal centrifugal pumps, etc. (Helfrich et al. 2001, 2004; McNabb et al. 2003; Thompson et al. 2011; van Esch et al. 2012, 2014). These studies included some of the same fish taxa as those in the turbine blade strike studies described above -- rainbow trout, striped bass, American eel, Chinook salmon Oncorhynchus tshawytscha, and Sacramento splittail Pogonichthys macrolepidotus. However, like the hydrokinetic turbine studies, these tests consisted of releasing fish into operational pumps and assessing post-passage injury and survival, but with no individual information on whether or how blade contact occurred, and therefore not comparable to the ORNL, Turnpenny, and Alden studies.

\section{STUDY COMPARISONS}

\subsection{METHODS}

\subsubsection{Strike Devices}

The Turnpenny and Alden devices are most similar of the three, though all devices impart a blade of similar leading-edge shape most often to the lateral midsection of a fish. All three devices include temporary restraining systems designed to allow the fish body to respond in a natural way after blade contact. In addition, all the systems utilized high-speed cameras to quantify blade velocity and for poststrike analysis of strike location and fish orientation.

\subsubsection{Fish Species}

The three groups of researchers who have conducted controlled laboratory blade strike studies (i.e., ORNL, Turnpenny, Alden) have tested a combined 10 different species from six different families (Table 1). Rainbow trout were tested in all three studies, and is the only species tested in more than one study. Although only one species was tested in more than one study, we would expect that species from the same family should have similar responses to blade strike given the high degree of similarity in physical attributes among most species within a family. All three studies conducted experiments with live anesthetized fish, although Turnpenny also included a series of studies on freshly euthanized fish. 
Table 1. Species used in blade strike studies reported in ORNL, Turnpenny, and Alden studies.

\begin{tabular}{|l|c|c|c|}
\hline Taxa & ORNL & Turnpenny & Alden \\
\hline Salmonidae & $\mathrm{X}$ & $\mathrm{X}$ & $\mathrm{X}$ \\
\hline Rainbow trout (RBT, Oncorhynchus mykiss) & & $\mathrm{X}$ & \\
\hline Brown trout (BRT, Salmo trutta) & $\mathrm{X}$ & & \\
\hline Clupeidae & & $\mathrm{X}$ & \\
\hline Gizzard shad (GZS, Dorosoma cepedianum) & & $\mathrm{X}$ & \\
\hline Atlantic herring (Clupea harengus) & & \\
\hline Anguillidae & & \\
\hline European eel (EEL, Anguilla anguilla) & & $\mathrm{X}$ \\
\hline American eel (AEL, Anguilla rostrate) & $\mathrm{X}$ & \\
\hline Moronidae & & $\mathrm{X}$ \\
\hline Hybrid striped bass (STH, M. saxatilus X M. chrysops) & & \\
\hline European bass (EBS, Dicentrarchus labrax) & & $\mathrm{X}$ \\
\hline Other & & \\
\hline Sand smelt (Atherina presbyter) & & \\
\hline White sturgeon (WST, Acipenser transmontanus) & & \\
\hline
\end{tabular}

\subsubsection{Blade Width}

Turnpenny (1992) was the first to note that fish injury decreased with increasing thickness of the leading edge. The three research groups have tested a range of leading edge widths - Alden tested five widths from $9.5-150 \mathrm{~mm}$, Turnpenny tested four widths from 10-100 mm, and ORNL has tested two widths 26 and $52 \mathrm{~mm}$ to date (Figure 6).

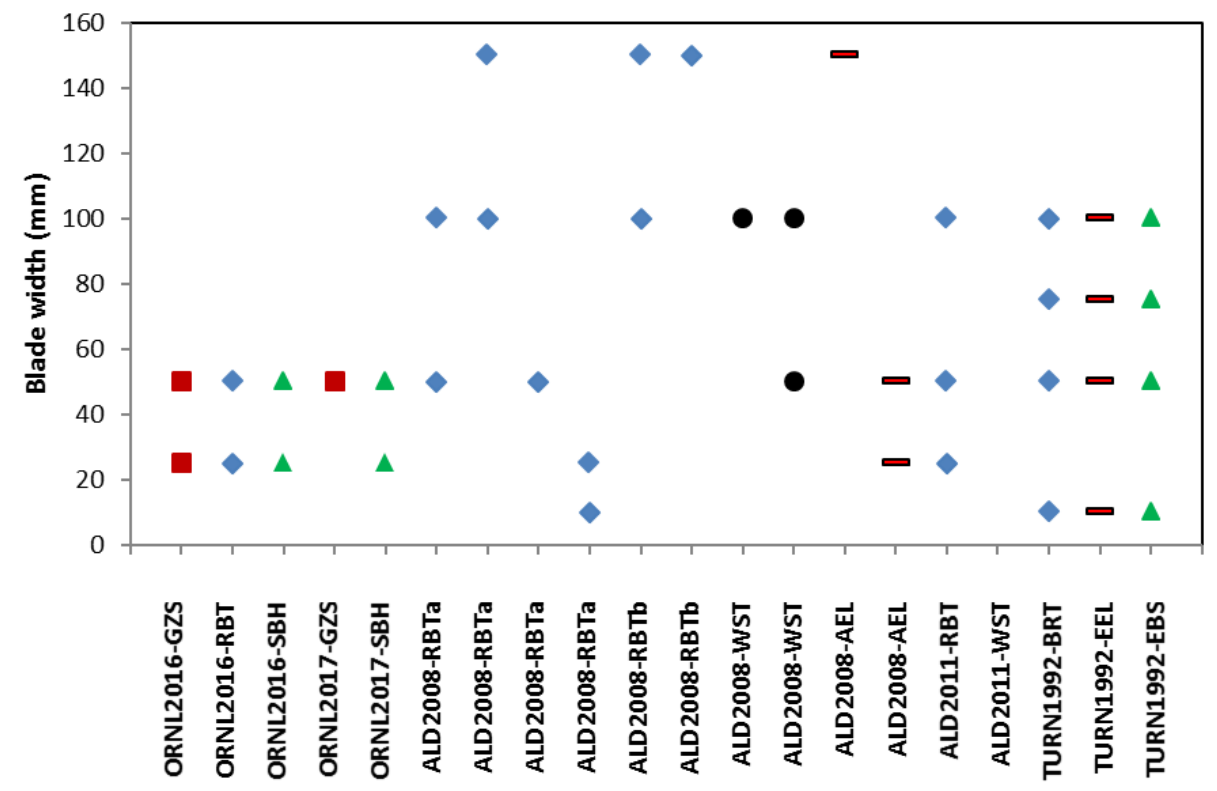

Figure 6. Leading edge blade widths $(\mathrm{mm})$ tested in ORNL, Alden, and Turnpenny studies ordered left to right by research group, study or report year, and species. Species codes in the $\mathrm{x}$-axis label are as in Table 1, and fish in common families across the different studies have the same symbols

( $\square$ Clupeids, $\diamond$ Salmonids, $\Delta$ Moronids, $\bullet$ Acipenserids, - Anguillids). 


\subsubsection{Blade Velocity}

Alden tested roughly seven velocities from 3.0 to $12.2 \mathrm{~m} / \mathrm{s}$, Turnpenny four velocities from 5.2 to $7.1 \mathrm{~m} / \mathrm{s}$, and ORNL has tested roughly six velocities from 7.3 to $10.1 \mathrm{~m} / \mathrm{s}$. None of the groups tested all velocities with all species or with all blade widths (Figure 7). It is important to note that the velocities tested in these studies with stationary fish are analogous to the net difference in velocity between a fish passing through a turbine and the turbine blade itself which is usually lower than the blade speed relative to a stationary reference. This is true for all of the studies reviewed.

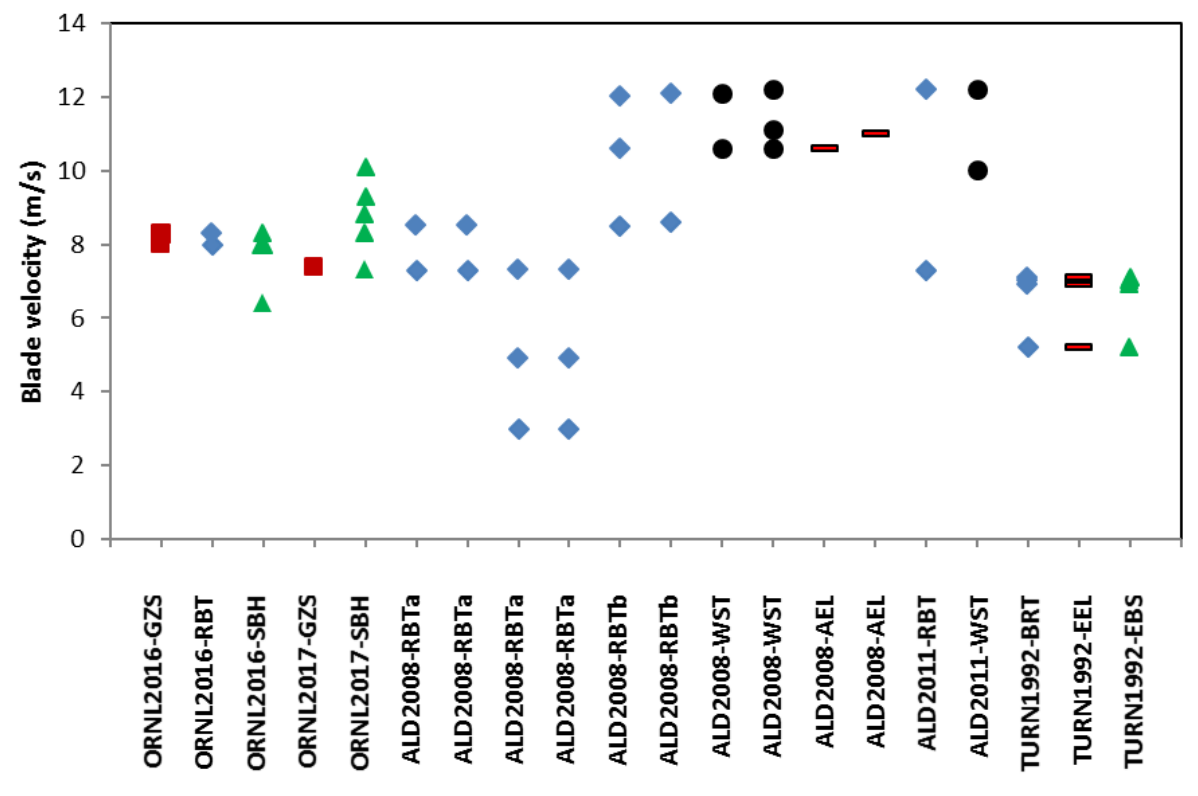

Figure 7. Blade velocities $(\mathrm{m} / \mathrm{s})$ tested in ORNL, Alden, and Turnpenny studies ordered by report year and species. Species codes in the $\mathrm{x}$-axis label are as in Table 1, and fish in common families across the different studies have the same symbols

( $\square$ Clupeids, $\diamond$ Salmonids, $\Delta$ Moronids, $\bullet$ Acipenserids, - Anguillids). 


\subsubsection{Fish Size}

Except for some adult eels tested by Alden and Turnpenny, the mean length of fish used in the studies are largely similar, ranging from 10 to $30 \mathrm{~cm}$ (Figure 8). American eels (group means of 248-680 mm) and rainbow trout (group means of 101-244 $\mathrm{mm}$ ) had the largest range in sizes for individual species.
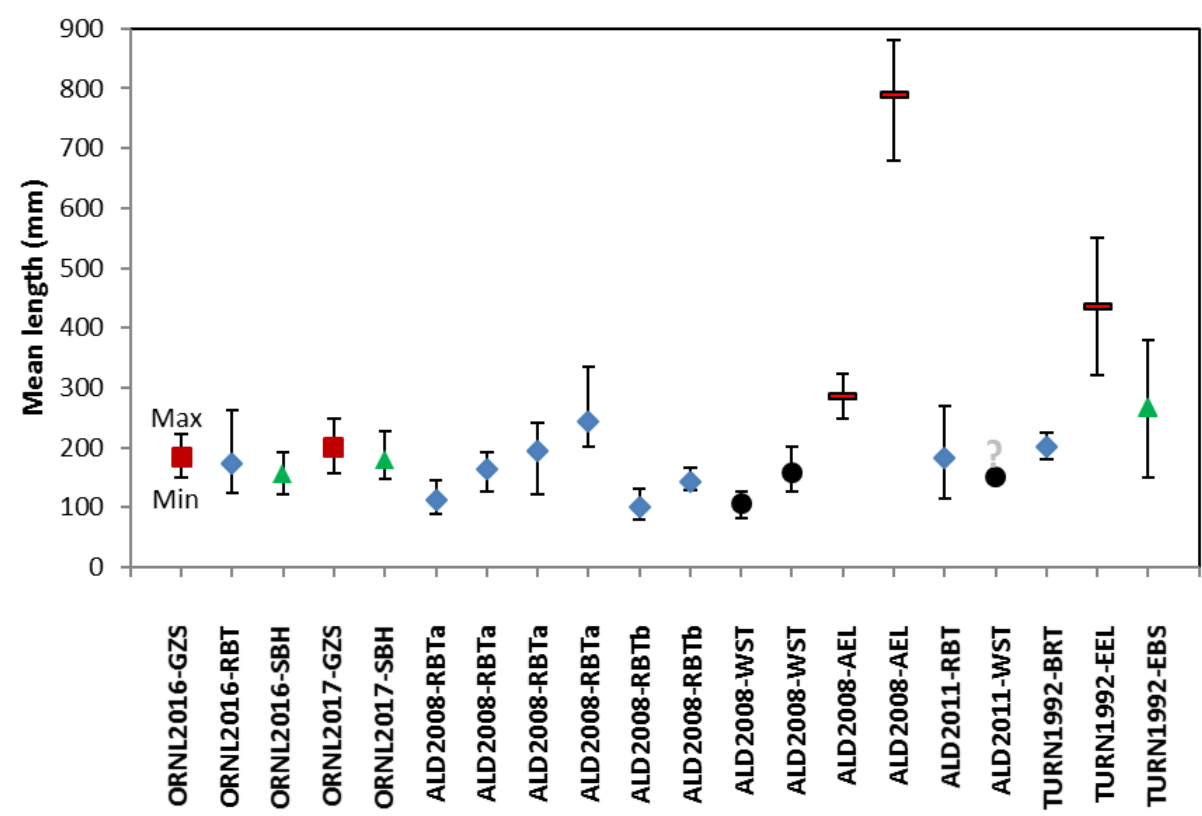

Figure 8. Minimum, maximum, and mean lengths $(\mathrm{mm})$ of fish tested in ORNL, Alden, and Turnpenny studies ordered by report year and species. Species codes in the $\mathrm{x}$-axis label are as in Table 1, and fish in common families across the different studies have the same symbols ( $\square$ Clupeids, $\diamond$ Salmonids, $\Delta$ Moronids, $\bullet$

Acipenserids, - Anguillids). The precise ranges of lengths for Alden 2011 studies are unknown. 


\subsubsection{L/t Ratio}

Alden researchers first recognized that considering blade width in combination with fish size (i.e., length) provided a good indicator of strike survival. Turnpenny and Alden researchers tested a wide range of fish length to blade width ratios, 2.0 to 26.5 for Turnpenny and 0.8 to 24.4 for Alden (both ranges excluding eel values which were much larger; Figure 9). Because the Turnpenny and Alden studies clearly showed that high ratios typically resulted in complete mortality and low values typically resulted in complete survival, ORNL studies were designed to test a mid-range of L/t ratios (3.6 to 7.2) where more uncertainty exists with regards to injury and survival.

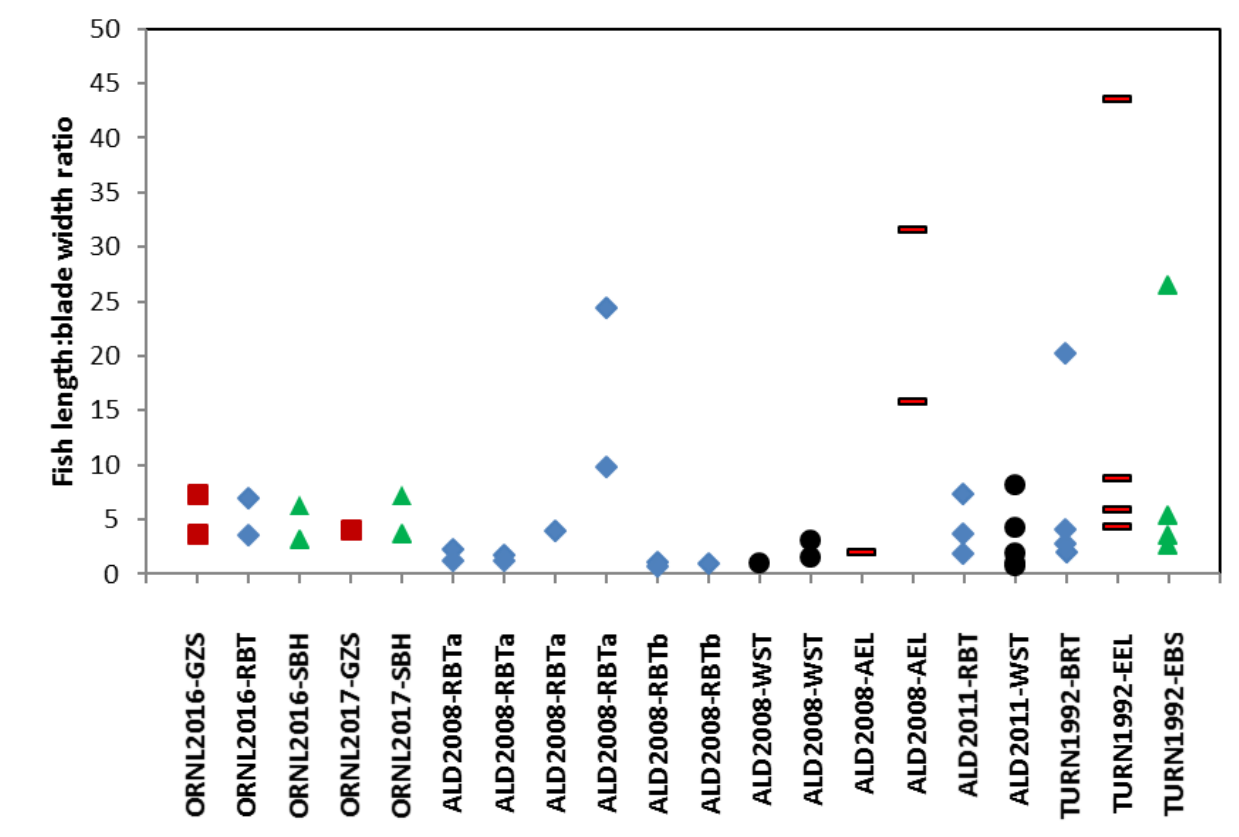

Figure 9. Fish length to blade width ratios (L/t) tested in ORNL, Alden, and Turnpenny studies ordered by report year and species. Species codes in the $x$ axis label are as in Table 1, and fish in common families across the different studies have the same symbols

( $\square$ Clupeids, $\diamond$ Salmonids, $\Delta$ Moronids, $\bullet$ Acipenserids, - Anguillids).

\subsubsection{Fish Orientation}

The ORNL and Alden studies arranged fish for head and tail strikes as well as mid-section strikes, whereas the location of strike in Turnpenny studies was intended to be midsection but post-processing identified some head and tail strikes. Only ORNL purposefully struck fish on the dorsal or ventral edge, though both Alden and Turnpenny noted some non-lateral strikes after post-processing. Both the ORNL and Alden studies placed fish in different angled orientations prior to strike. In addition to the normal $90^{\circ}$ orientation (i.e., perpendicular to the blade), ORNL also directed strikes at $45^{\circ}$ angles to both head and midsection in both head-first $\left(45^{\circ}\right)$ and tail-first $\left(225^{\circ}\right)$ orientations. Alden also conducted a series of angled strikes in their 2011 study, but they were limited only to $45^{\circ}$ strikes to the midsection in the headfirst $\left(45^{\circ}\right)$ orientation. 


\subsubsection{Injury Assessment}

The three groups of studies all assessed injuries following blade strike, but in slightly different ways. ORNL assessed both external injuries and internal injuries including abrasions, contusions, lacerations, hemorrhaging, broken bones and spines, and rupturing of external features and internal organs and descaling. Alden and Turnpenny assessed virtually the same list of external injuries but did not assess internal injuries and neither included an analysis of whether there was a relationship among different strike factors (e.g., blade velocity, strike location, strike angle) and types of injury.

\subsubsection{Survival Assessment}

All studies assessed immediate and latent survival post-strike, but not on the exact same time frames. Turnpenny and Alden studies assessed survival immediately after the strike and then again at $168 \mathrm{hr}$ and $96 \mathrm{hr}$, respectively, for any survivors. ORNL studies assessed survival immediately after the strike for all fish and during the first hour after strike and then again at $48 \mathrm{hr}$ for a subset of about $20 \%$ of the fish tested.

\section{EXPERIMENTAL RESULTS}

The primary purpose of this report is to summarize and compare the study designs and treatment combinations of blade strike studies conducted by ORNL and other researchers. A brief comparison of experimental results is included here, but a more detailed comparison of results will be included in a manuscript describing the ORNL 2016 and 2017 studies to be completed at the end of 2017.

\subsection{SURVIVAL}

All three studies used survival as the primary endpoint. ORNL results from 2016 are summarized in Figure 10. Key ORNL findings in 2016 were:

- Differences in survival among species - Striped bass $>$ trout $>$ shad

- Differences in survival as function of location of blade impact- tail $>$ head $>$ midsection

- Differences in survival as function of blade width $-52 \mathrm{~mm}>26 \mathrm{~mm}$

In 2017, gizzard shad and striped bass hybrids were tested again with additional factors that included additional velocities, strike locations, and strike angles. Key findings in 2017 include:

- Compared to midsection lateral (side) strikes, the survival rates of fish struck at the dorsal and ventral aspects (also middle of fish) were significantly higher for both shad and bass

- Angled strikes to the midsection aimed toward the head caused as much mortality as a midsection straight on strike

- Angled midsection strikes toward the tail produced few mortalities 


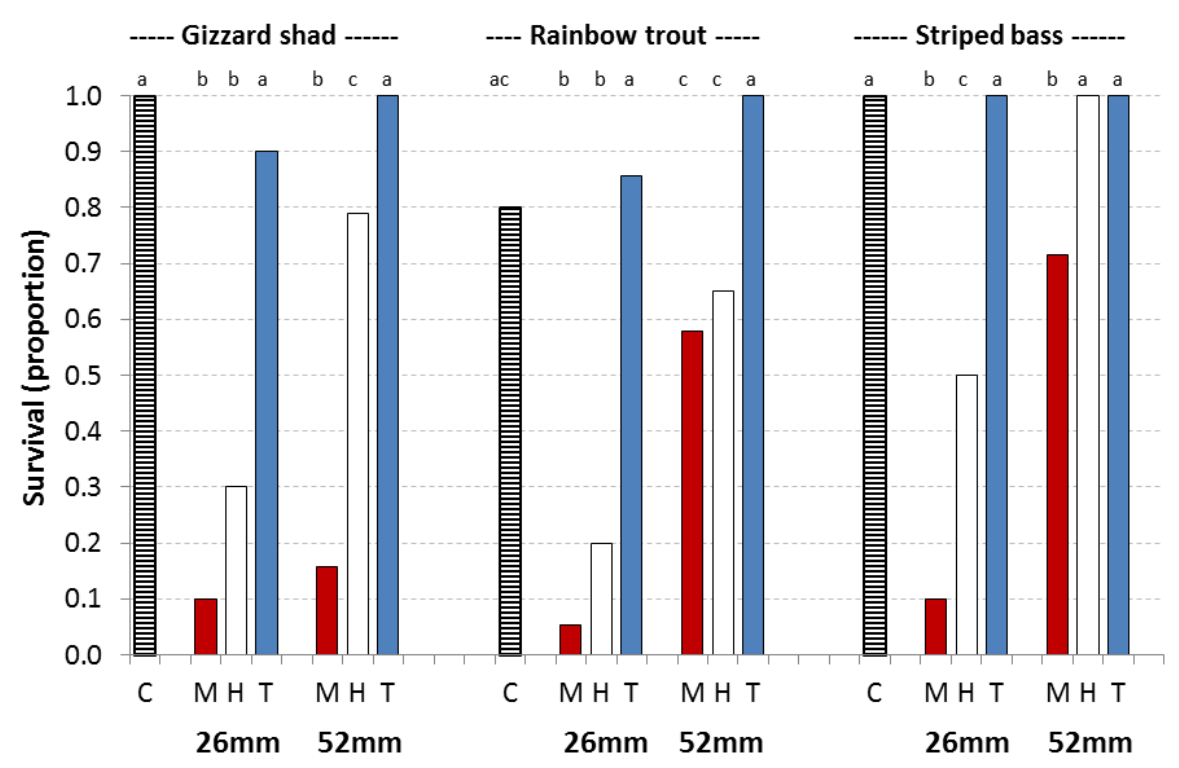

Figure 10. One-hour survival results of ORNL 2016 strike treatments (species by blade width by strike location). Within each species, treatments with the same letter across top of graph are not significantly different from each other. $\mathrm{C}=$ control, $\mathrm{M}=$ midsection strikes, $\mathrm{H}=$ head strikes, and $\mathrm{T}=$ tail strikes.

The most relevant prior work that presents a useful comparison to the ORNL results is that reported in EPRI (2008, 2011) and Amaral et al. (2015). One of the key findings in that series of studies was that survival generally decreases as the ratio of fish length to blade width, L/t, increases (Figure 11). The Alden studies found nearly $100 \%$ survival of rainbow trout, with a $\mathrm{L} / \mathrm{t}$ ratio of 0.75 up to a strike speed of $12 \mathrm{~m} / \mathrm{s}$; survival of $\sim 75$ to $100 \%$ for a L/t of 1 at speeds of 7 to $12 \mathrm{~m} / \mathrm{s}$, respectively; survival of $\sim 60$ to $100 \%$ for a $\mathrm{L} / \mathrm{t}$ of 2 at speeds of 5 to $12 \mathrm{~m} / \mathrm{s}$, respectively; and survival of $\sim 50$ to $100 \%$ for a $\mathrm{L} / \mathrm{t}$ of $10-25$ at speeds of 5 to $7 \mathrm{~m} / \mathrm{s}$, respectively. We found slightly lower survival rates for rainbow trout: $65 \%$ head and $57 \%$ midsection strikes at a $\mathrm{L} / \mathrm{t}$ of $\sim 3.4$, and $20 \%$ head and $5 \%$ midsection strikes at a $\mathrm{L} / \mathrm{t}$ of $\sim 6.5$ at a blade speed of $8 \mathrm{~m} / \mathrm{s}$ (see Figure 11). We consider these results to be relatively consistent, given the differences in methods and fish sizes and origins.

Turnpenny et al. (1992) also conducted trials with a salmonid species (brown trout) but with only a few different combinations of velocity and blade widths. They found $100 \%$ survival at velocity of $5 \mathrm{~m} / \mathrm{s}$ and $\mathrm{L} / \mathrm{t}$ of 2.0 , and no survival at velocities from 6.9 to $7.1 \mathrm{~m} / \mathrm{s}$ and corresponding $\mathrm{L} / \mathrm{t}$ of 2.7 to 20.2 (see Figure 11).

Similarly, for other species we found mortality rates for gizzard shad to be about the same: mortality of $\sim 53 \%$ for a $\mathrm{L} / \mathrm{t}$ ratio of 3.7 and $\sim 80 \%$ for a $\mathrm{L} / \mathrm{t}$ ratio of 7.4 at $8 \mathrm{~m} / \mathrm{s}$. Rates for striped bass were a bit lower: mortality of $\sim 14 \%$ for a L/t of 3.0 and $\sim 70 \%$ for a L/t of 6.3 at $8 \mathrm{~m} / \mathrm{s}$. Additionally, we found no mortality for striped bass for a $\mathrm{L} / \mathrm{t}$ of 6.4 at a blade speed of $6 \mathrm{~m} / \mathrm{s}$. We expect results among species to vary, given that fish shape and musculature vary markedly among species. We believe a less speciesspecific relationship could be derived if, instead of being based solely on length, the ratio of fish length to blade width also included a measure of fish mass or center of gravity. 


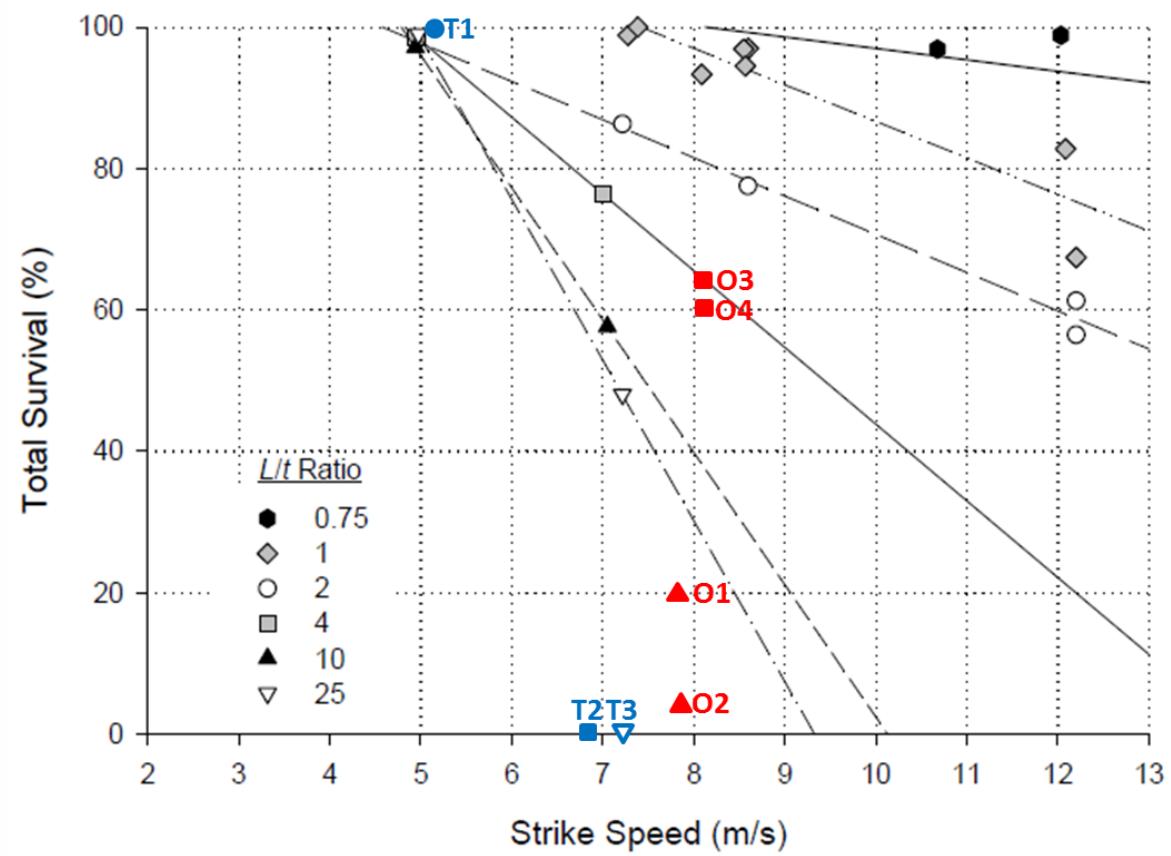

Figure 11. This base figure (in gray scale) summarizes the results of rainbow trout strike studies conducted at Alden Laboratories and reported in EPRI (2011). The red and blue points are similar values from ORNL (O1O4) and Turnpenny (T1-T3) studies for rainbow and brown trout, respectively. Added symbol shapes correspond to $\mathrm{L} / \mathrm{t}$ ratio legend. Key: $\mathrm{O} 1=$ head strike, $\mathrm{L} / \mathrm{t}=6.4 ; \mathrm{O} 2=$ midsection strike, $\mathrm{L} / \mathrm{t}=6.7 ; \mathrm{O} 3=$ head strike, $\mathrm{L} / \mathrm{t}=3.4 ; \mathrm{O} 4=$ midsection strike, $\mathrm{L} / \mathrm{t}=3.3 ; \mathrm{T} 1=$ midsection strike, $\mathrm{L} / \mathrm{t}=2.0 ; \mathrm{T} 2=$ midsection strike, $\mathrm{L} / \mathrm{t}=4.0 ; \mathrm{T} 3=$ midsection strike, $\mathrm{L} / \mathrm{t}=20.2$.

Eels (Anguilla spp.) were tested by both Turnpenny and Alden but not by ORNL (although ORNL has plans to test eels in late 2017). Turnpenny found eels struck at 5.2 and $6.9 \mathrm{~m} / \mathrm{s}$ with a thick blade (100 and $75 \mathrm{~mm}$, respectively) had nearly $100 \%$ survival, while those struck at 7.0 and $7.1 \mathrm{~m} / \mathrm{s}$ with a thin blade (50 and $10 \mathrm{~mm}$, respectively) had nearly $100 \%$ mortality. One reason that Turnpenny results seem to be either $100 \%$ mortality or $100 \%$ survival is because they only evaluated survival for those fish that met their definition of a 'positive strike' which was the fish being wrapped around the blade at impact. Those fish that were deflected to the side were considered to not have been fully struck and were not assessed for injury or survival. This also led Turnpenny to identify the importance of the position of a fish's center of gravity relative to the path of the blade in increasing the likelihood of a severe outcome.

\subsubsection{Injury}

All three research groups evaluated external injuries but only ORNL assessed internal injuries as well. For the 2016 studies at ORNL we assessed whether the rates of occurrence of different injuries were related to the strike treatment and whether any injuries were related to individual mortality; 2017 injury results are still being analyzed. Although there were differences among the three species, injuries that were associated with strike treatments included external bleeding, eye damage, gill damage, operculum damage, internal bleeding, and swim bladder damage, with swim bladder damage being a common strikeinduced injury for all species. We also found that external bleeding, gill damage, internal bleeding, and swim bladder damage are good indicators of eventual mortality. Bruising and lacerations were the most common injuries reported in Alden (2008) studies; they did not analyze for associations among injury types and mortality. The most common injuries observed in the Turnpenny studies included heavy scale and mucous loss, crushing of muscle, spinal fracture, and internal bleeding (Turnpenny 1998). 


\subsubsection{Angled Strikes}

Angled trials by Alden (2011) were limited to only $45^{\circ}$ strikes (i.e., strike direction toward the tail) and they found survival rates higher than $90^{\circ}$ hits which is consistent with our findings. Strikes at that angle are away from the center of gravity of the fish and usually result in a deflection instead of a direct strike. On the other hand, in addition to strikes at $45^{\circ}$ and $90^{\circ}$, ORNL tested strikes at $225^{\circ}$ (i.e., a $45^{\circ}$ strike from tail to head) aimed at both the head and midsection (see Figure 9). A midsection strike at this angle places the fish's center of gravity close to the blade path and exposes the gill area to a direct strike. The importance of accounting for strike angle and orientation in blade strike models has been highlighted by Ploskey and Carlson (2004) and Deng et al. (2005) and identified as a critical source of model uncertainty.

\subsubsection{Sample Sizes}

Sample sizes in studies by ORNL and Alden are similar; those used in Turnpenny studies were not reported in either of the two project summaries used in this review. In two years of strike experiments, ORNL exposed $\sim 120$ rainbow trout, 290 gizzard shad, and $\sim 440$ striped bass hybrids (not counting control fish) to blade strike, and in two years of experiments Alden exposed $\sim 1,090$ rainbow trout, 250 white sturgeon, and 100 American eels. For any treatment combination (blade width, velocity, strike location, angle, etc.) the target sample size in ORNL studies was 15, 20, or 24. Sample sizes for the Alden studies are a little less straightforward. Because strike location and angle were somewhat random functions of how the fish was located when struck they did not have equal sample sizes for all strike combinations. For example, sample size for lateral midsection hits (at different blade width and velocity combinations) averaged about 27 for rainbow trout, 20 for sturgeon, and 37 for eel. Other strike locations and angles, e.g., head or dorsal were normally less than 10 per treatment combination.

\section{DATA GAPS AND FUTURE RESEARCH DIRECTION}

The results of the blade strike studies reviewed in this report contribute dose-response relationships that are needed to parameterize the BioPA model that predicts the fate of fish that pass through hydropower turbines (Richmond et al. 2014). It is important to the success of the BioPA that the model have the capacity to address many species and a wide distribution of strike scenarios. After reviewing past and present blade strike studies, we better understand the magnitude of the range of responses and are better able to evaluate what range of each variable (e.g., blade velocity, fish length, strike angle) needs testing to define the envelop of possible responses for enough conditions to populate the BioPA model. We also need to understand how many different species need to be tested in order to represent the range of species that could be affected by turbine passage. This discussion on data gaps and future research direction is focused on species, the blade (i.e., width and velocity) strike orientation (i.e., body location and angle), and response variables.

\subsection{SPECIES}

The studies reviewed in this report have been able to test strike effects on a combined 10 species (see Table 1) but with only a few combinations of strike factors for most species. Given the magnitude of among-species differences in response to strike due to differences in morphology (e.g., musculature, center of gravity, integument, and mass), it is important that enough species are tested to be able to make 
justifiable inferences about the expected responses of many other species so that testing of all is not necessary for inclusion in the BioPA.

Pracheil et al. (2016a, 2016b) provides lists of species affected by hydropower operations that are representative of a variety of body types and feeding strategies for broadening our understanding of blade-strike effects on fishes. Based on those lists and on expert opinion within our team we generated a list of targeted taxa and surrogate or representative species for all the dose response studies (Table 2). In FY 2018 and beyond we plan to expand the list of tested species to better represent those listed in Table 2 under combinations of conditions that are most indicative of the exposure in actual turbines (i.e., known leading edge widths and velocities) and that provide the most information about injury and mortality.

Table 2. Summary of current priority species and life stages for the BioDE dose-response studies. (Source BioDE MYRP 2017)

\begin{tabular}{|c|c|c|c|c|c|}
\hline Species Group & Species & Life Stages & Region & Justification & $\begin{array}{l}\text { Proposed Surrogate } \\
\text { Species }\end{array}$ \\
\hline \multirow{3}{*}{$\begin{array}{l}\text { Family } \\
\text { Salmonidae }\end{array}$} & Steelhead & Juv\&Adult & PNW & Listed under ESA & Rainbow trout \\
\hline & Bull trout & Juv\&Adult & PNW & Listed under ESA & $\begin{array}{l}\text { Brook trout, lake trout } \\
\text { (shear, blade strike) }\end{array}$ \\
\hline & Atlantic salmon & Juv\&Adult & $\begin{array}{l}\text { East } \\
\text { Coast } \\
\text { (Gulf of } \\
\text { Maine) }\end{array}$ & Listed under ESA & None \\
\hline \multirow[t]{3}{*}{$\begin{array}{l}\text { Family } \\
\text { Clupeidae }\end{array}$} & American shad & Juv\&Adult & $\begin{array}{l}\text { Atlantic } \\
\text { coast }\end{array}$ & Listed under ESA & Gizzard shad \\
\hline & Blueback herring & Juv\&Adult & $\begin{array}{l}\text { Atlantic } \\
\text { coast }\end{array}$ & Listed under ESA & $\begin{array}{l}\text { Gizzard shad } \\
\text { American shad }\end{array}$ \\
\hline & Alewife & & $\begin{array}{l}\text { Atlantic } \\
\text { coast }\end{array}$ & Species of Concern for NOAA & $\begin{array}{l}\text { Gizzard shad } \\
\text { American shad }\end{array}$ \\
\hline \multirow[t]{3}{*}{$\begin{array}{l}\text { Family } \\
\text { Centrarchidae }\end{array}$} & Largemouth bass & Juv\&Adult & All & $\begin{array}{l}\text { Commonly found throughout } \\
\text { US; popular gamefish }\end{array}$ & $\begin{array}{l}\text { Bluegill (rapid } \\
\text { decompression, shear) }\end{array}$ \\
\hline & Smallmouth bass & Juv\&Adult & All & $\begin{array}{l}\text { Commonly found throughout } \\
\text { US; popular gamefish }\end{array}$ & $\begin{array}{l}\text { Bluegill (rapid } \\
\text { decompression, shear) }\end{array}$ \\
\hline & Bluegill* & Adult & All & $\begin{array}{l}\text { Commonly found in US; } \\
\text { Physoclistous }\end{array}$ & Lepomis spp. \\
\hline \multirow[t]{3}{*}{$\begin{array}{l}\text { Order } \\
\text { Perciformes }\end{array}$} & Yellow Perch* & Juv\&Adult & All & $\begin{array}{l}\text { Commonly found throughout } \\
\text { US; Physoclistous (closed swim } \\
\text { bladder) }\end{array}$ & None \\
\hline & Walleye & Juv\&Adult & $\begin{array}{l}\text { North } \\
\text { and } \\
\text { Midwest }\end{array}$ & $\begin{array}{l}\text { Commonly throughout US; } \\
\text { popular gamefish }\end{array}$ & None \\
\hline & Sauger & All & All & $\begin{array}{l}\text { Commonly found throughout } \\
\text { US; popular gamefish; migratory }\end{array}$ & None \\
\hline
\end{tabular}




\begin{tabular}{|c|c|c|c|c|c|}
\hline Species Group & Species & Life Stages & Region & Justification & $\begin{array}{l}\text { Proposed Surrogate } \\
\text { Species }\end{array}$ \\
\hline & Striped bass & $\begin{array}{l}\text { Larvae } \\
\text { Adult }\end{array}$ & $\begin{array}{l}\text { Atlantic } \\
\text { coast } \\
\text { U.S. }\end{array}$ & $\begin{array}{l}\text { Downstream drifting larvae; } \\
\text { popular gamefish }\end{array}$ & $\begin{array}{l}\text { Hybrid striped bass } \\
\text { White bass }\end{array}$ \\
\hline \multirow[t]{2}{*}{$\begin{array}{l}\text { Order } \\
\text { Cypriniformes }\end{array}$} & Blue sucker & Adult & $\begin{array}{l}\text { Miss. and } \\
\text { Missouri } \\
\text { rivers }\end{array}$ & Migratory & None \\
\hline & White sucker & Adult & $\begin{array}{l}\text { Midwest, } \\
\text { NE, } \\
\text { South }\end{array}$ & Commonly found throughout US & \\
\hline \multirow[t]{2}{*}{$\begin{array}{l}\text { Order } \\
\text { Acipen- } \\
\text { seriformes }\end{array}$} & $\begin{array}{l}\text { Sturgeon (All } \\
\text { species) }\end{array}$ & $\begin{array}{l}\text { Larvae } \\
\text { Juvenile } \\
\text { Adult }\end{array}$ & All & $\begin{array}{l}\text { Conservation concern/listed } \\
\text { under ESA; popular gamefish; } \\
\text { downstream drifting larvae }\end{array}$ & None \\
\hline & Paddlefish & $\begin{array}{l}\text { Larvae } \\
\text { Juvenile } \\
\text { Adult }\end{array}$ & $\begin{array}{l}\text { Mississip } \\
\text { pi River } \\
\text { Basin }\end{array}$ & $\begin{array}{l}\text { Conservation concern/listed } \\
\text { under ESA; popular gamefish; } \\
\text { downstream drifting larvae }\end{array}$ & None \\
\hline $\begin{array}{l}\text { Order } \\
\text { Anguillidae }\end{array}$ & American eel & Adult & $\begin{array}{l}\text { Atlantic } \\
\text { and Gulf } \\
\text { coast }\end{array}$ & $\begin{array}{l}\text { Conservation concern; } \\
\text { downstream migrating adults }\end{array}$ & None \\
\hline
\end{tabular}

\subsubsection{Blade Width and Velocity}

Turbine runner blades and their leading edge widths come in all shapes and sizes. Similarly, rotational speeds and therefore velocities also vary among turbines. For axial flow turbines (i.e., Kaplan) blade width and velocity are tightly linked, since runner blades typically taper from thickest at the hub to thinnest at the tip and velocities are slowest near the hub and fastest near the tip.

From the first study by Turnpenny et al. (1992), blade strike researchers have recognized the importance of leading edge width with respect to the potential for causing injury. There are several likely explanations for why thinner blades cause more damage including : 1) thicker blades produce a larger bow wave at the front of the blade that cushions the blow and can even move small fish out of the way enough to minimize actual blade contact, 2) thicker blades cause the force of the impact to be spread over a larger surface area of the fish's body, and 3) because a direct strike seems to bend a fish around the blade regardless of its width, thick blades do not cause as severe a bend as do thin blades likely resulting in less severe injury. Collectively, the studies reviewed for this report tested a wide range of blade widths and velocities. Based on these data, for several species we are able to begin to identify what blade widthvelocity combinations are unlikely to result in mortality and which combinations are likely to result in near $100 \%$ mortality. In between these extremes there is still much uncertainty with regards to what combinations of width and velocity and other factors (i.e., species, size, and orientation) result in injury and mortality. The range of speeds we can achieve with the $26-\mathrm{mm}$ blade $(6-10 \mathrm{~m} / \mathrm{s})$ is adequate for the size of fish currently tested. Faster velocities with the 52-mm blade (present max is $\sim 8.3 \mathrm{~m} / \mathrm{s}$ ) is desirable for a more direct comparison to the 26-mm blade. For future studies at ORNL, increasing the blade width and blade velocity will require construction of a slightly more powerful test apparatus, but as strike devices go, this device is relatively low cost, and a faster or larger strike simulator is within the current budget. 


\subsubsection{Strike Orientation}

With regards to body location and angle of strike, Computational Fluid Dynamics (CFD) model traces like those used to inform the BioPA model can estimate a likelihood of strike, but presently we can only assume that the strike has equal probabilities of hitting any location on the body and any orientation. Because we presently have no reason to believe that one location is more likely to be struck than any other, our goal is to be able to assign a probability of injury, including mortality, to all possible strike locations and orientations for incorporation into BioPA. Obviously not every possible orientation can be tested, but by testing enough locations and angles, we can develop key relationships about the relative susceptibility of different orientations and then through extrapolation develop a whole-body risk of injury or mortality. We have already confirmed that tail strikes are almost always inconsequential and that no additional testing of strike at that location is needed allowing us to concentrate on locations where greater damage is expected, i.e., the midsection and the head. Similarly, with trials on 2-3 more species with ventral and dorsal strikes we think we will be able to surmise that those orientations are less damaging (and less likely to occur) than lateral strikes and need no further investigation. After viewing the highspeed videos collected during the ORNL trials, it appears that unless the ventral and dorsal strikes are balanced on the blade edge at strike (i.e., nearly perfectly at a right angle to the blade), the fish is turned at impact into a lateral strike position.

In 2017 we learned through angled tests that not just the angle is important but from which direction the angled blow is initiated, i.e., from the head or tail. There is a great deal yet to be learned about the relationships among fish mass, length, location of center of gravity, and the angle and location of blade strike. It is important than studies be continued with key angles of strike at key body locations so that these relationships can be defined.

\subsubsection{Response Variables}

The primary response variable of interest is mortality, more specifically direct mortality that occurs in a short time after strike. Our studies found that fish that were swimming normally after the first hour following strike are likely to survive long-term as well. Therefore, as in 2017 studies we will continue to hold fish for only an hour after strike and define mortality as those fish that die within that time and those that are 'ecologically' dead, i.e., those that exhibit external bleeding or inability to swim upright or maintain normal equilibrium.

It is important that we continue to assess external and internal injuries so that we can better understand the source of mortalities and how different aspects of blade strike differentially affect species with different integument protection and different skeletal and musculature support.

\subsubsection{Recommendations}

In future studies, we propose the following study design priorities:

- Testing additional species from the list developed for the MYRP

- Continued comparison of key strike angles and body locations

- Head and midsection at $90^{\circ}$

- Head at $45^{\circ}$

- Head and midsection at $225^{\circ}$

- A slightly larger variation in fish sizes, both smaller and larger (for one or two key species only). Fish mass is an extremely important variable in predicting survival; the relationships defined for one size of fish will not likely be the same for larger or smaller fish. Larger fish 
(i.e., higher L/t ratio) generally absorb more of the force of impact and therefore are more likely to be injured especially by thin blades. However, adult fish are more difficult to acquire in large numbers. A few key studies are desirable.

- Faster blade velocities up to $12 \mathrm{~m} / \mathrm{s}$. Because blade velocity varies within a turbine (e.g., slow near the hub and fast near the tips for Kaplan turbines) it is important that dose response relationships be defined across a range of velocities. Although some blade tip speeds exceed $30 \mathrm{~m} / \mathrm{s}$, testing above $12-14 \mathrm{~m} / \mathrm{s}$ is typically not necessary as strikes above those speeds are usually fatal.

- Addition of single larger blade, 75 to $100 \mathrm{~mm}$ thickness. The thicknesses we have already tested are representative of the blade thickness for most of the leading edge of most turbine runners. However, blades are typically much thicker where they attach to the hub in propeller or bulb turbines (e.g., Kaplan turbines) and there are combinations of moderate thickness and velocity that can still be injurious. On the other hand, the two blade thicknesses we have been testing probably capture most of the range turbine blades thickness in Francis turbines.

Given the multitude of combinations of blade velocity, blade width, and fish length, it is important that we focus future studies on combinations of those three factors that produce responses that are between no effect and $100 \%$ mortality. We should avoid as much as possible combinations that have no effect or total mortality, except to define the boundaries of the strike response envelope. As we discover relationships for certain variables that are consistent among species, we hope to be able to focus future studies such that fewer combinations of variables will be needed to develop robust, predictive doseresponse relationships for new species and to reduce the amount of laboratory experiments needed to add species-specificity into the BioPA Tool and guide the design of new hydropower turbines.

This review of blade strike effects on fish found only two other research efforts besides current studies at ORNL that tested specific blade strike factors on fish injury and mortality in a controlled setting. These studies tested many of the same or related fish species and all tested various combinations of blade velocity, blade width, and fish orientation. As mentioned above the combinations of factors are endless as is the need for more research, however, going forward, the lessons learned in these studies need to be combined with efficient future study design to best understand which combinations of factors produce the best and worst environmental outcomes.

\section{ACKNOWLEDGEMENTS}

This research was sponsored by the US Department of Energy's Office of Energy Efficiency and Renewable Energy, Water Power Technologies Program. We thank ORNL student interns Chioma Anugwom, Itohan Osaquwa, Emine Fidan, and Ryan Saylor for assistance on the ORNL laboratory experiments.

\section{REFERENCES}

Amaral, S.V., M.S. Bevelhimer, G.F. Čada, D.J. Giza, P.T. Jacobson, B.J. McMahon, and B.M. Pracheil. 2015. Evaluation of behavior and survival of fish exposed to an axial-flow hydrokinetic turbine. $\mathrm{N}$. Am. J. Fish. Manage. 35: 97-113. 
Amaral S.V., G.E. Hecker, P. Stacy, and D.A. Dixon. 2008. Effects of leading edge turbine blade thickness on fish strike survival and injury. Proceedings of 2008 HydroVision International. HCI Publications Paper no. 250. 14 pp.

Amaral S.V., G.E. Hecker, S. St. Jean, and D.A. Dixon. 2011. The effect of fish orientation on blade strike mortality and implications for predicting turbine passage survival. Proceedings of 2011 HydroVision International.

Čada, G. F., 2001. The development of advanced hydroelectric turbines to improve fish passage survival. Fisheries 26: 14-23.

Cook, T.C., G.E. Hecker, S.V. Amaral, P.S. Stacy, F. Lin, and E.P. Taft. 2003. Final report-pilot-scale tests Alden/Concepts NREC turbine. DOE/ID/13733, Alden Research Laboratory (US), Holden, MA.

Deng, Z., T. J. Carlson, G. R. Ploskey, M. C. Richmond. 2005. Evaluation of blade-strike models for estimating biological performance of hydro turbines. U.S. Department of Energy, Pacific Northwest National Laboratory, Report Number PNNL-15370.

Deng Z.D., T.J. Carlson, D.D. Dauble, and G.R. Ploskey. 2011. Fish passage assessment of an advanced hydropower turbine and conventional turbine using blade-strike modeling. Energies 4(1):57-67.

EPRI (Electric Power Research Institute). 2008. Evaluation of the effects of turbine blade leading edge design on fish survival. Prepared by Alden Research Laboratory Inc., EPRI Report No. 1014937.

EPRI (Electric Power Research Institute). 2011a. Fish passage through turbines: application of conventional hydropower data to hydrokinetic technologies. Prepared by Alden Research Laboratory Inc. EPRI Report No. TR-1024638.

EPRI (Electric Power Research Institute). 2011b. Evaluation of fish injury and mortality associated with hydrokinetic turbines. Prepared by Alden Research Laboratory Inc. EPRI Report No. TR-1024569.

EPRI (Electric Power Research Institute). 2012. Survival and behavior of juvenile Atlantic salmon and adult American shad on exposure to a hydrokinetic turbine. Prepared by S.O. Conte Anadromous Fish Research Center. EPRI Report No. TR-1026904.

Helfrich, L.A., R. Bark, C.R. Liston, D.C. Weigmann, and B. Mefford. 2004. Live transport of striped bass and rainbow trout using a hidrostal pump. J. World Aquacult. Soc. 135(2): 268-273.

Helfrich, L.A., C.R. Liston, B. Mefford, and R. Bark. 2001. Survival and injury of splittail and Chinook salmon passed through a large hidrostal pump. N. Am. J. Fish. Manage. 21(3):616-623.

Mathur, D., P.G. Heisey, E.T. Euston, J.R. Skalski, and S. Hays. 1996. Turbine passage survival estimation for Chinook salmon smolts (Oncorhynchus tshawytscha) at a large dam on the Columbia River. Can. J. Fish. Aquat. Sci. 53: 542-549.

Mathur, D., P.G. Heisey, J.R. Skalski, and D. R. Kenney. 2000. Salmonid smolt survival relative to turbine efficiency and entrainment depth in hydroelectric power generation. J. Am. Water Resour. As. 36(4): 737-747.

McNabb, C.D., C.R. Liston, and S.M. Borthwick. 2003. Passage of juvenile Chinook salmon and other fish species through Archimedes lifts and a hidrostal pump at Red Bluff, California. Trans. Am. Fish. Soc. 132(2): 326-334.

Ploskey, G. R., and T. J. Carlson. 2004. Comparison of blade-strike modeling results with empirical data. U.S. Department of Energy, Pacific Northwest National Laboratory, Report No. PNNL14603.

Pracheil, B.M., C.R. DeRolph, M.P. Schramm, and M.S. Bevelhimer. 2016a. A fish-eye view of riverine hydropower systems: Understanding the biological response to turbine passage. Rev. Fish Biol. Fisher. 26: 153-167. 
Pracheil, B.M., R.A. McManamay, M.S. Bevelhimer, C.R. DeRolph, and G.F. Čada. 2016b. A traitsbased approach for prioritizing species for monitoring and surrogacy selection. Endanger. Species Res. 31: 243-258.

Richmond M.C., J.A. Serkowski, C.L. Rakowski, B. Strickler, M. Weisbeck, and C.L. Dotson. 2014. Computational tools to assess turbine biological performance. Hydro Review 33: 88-98.

Schramm, M.P., M.S. Bevelhimer, and C.R. DeRolph. 2016. A synthesis of environmental and recreational mitigation requirements at hydropower projects in the United States. Environmental Science \& Policy 61: 87-96.

Schweizer, P.E., G.F. Cada, and M.S. Bevelhimer. 2012. Laboratory experiments on the effects of blade strike from hydrokinetic energy technologies on larval and juvenile freshwater fishes. ORNL/TM2012/108.

Thompson, A.M., J. Glasgow, T. Buehrens, and E.G. Drucker. 2011. Mortality in juvenile salmonids passed through an agricultural Hidrostal pump. Fisheries Management and Ecology 18(4): 333-338.

Turnpenny, A.W.H., M.H. Davis, J.M. Fleming, and J.K. Davies. 1992. Experimental studies relating to the passage of fish and shrimps through tidal power turbines. Marine and Freshwater Biology Unit, National Power, Fawley, Southampton, England.

Turnpenny, A.W.H. 1998. Mechanisms of fish damage in low-head turbines: an experimental appraisal. In Fish migration and fish bypasses. Edited by M. Jungwirth, S. Schmutz, and S. Weiss. Fishing News Books, Blackwell Publishing, Oxford, UK. pp. 300-314.

Turnpenny, A.W.H., G. Struthers, and P. Hanson. 2000. A UK guide to intake fish-screening regulations, policy and best practice with particular reference to hydroelectric power schemes. Energy Technology Support Unit, Department of Trade and Industry, Report No. ETSU H/O6/00052/REP.

van Esch, B.P.M. 2012. Fish injury and mortality during passage through pumping stations. Journal of Fluids Engineering 134(7): 071302 (9 pages).

van Esch, B.P.M., and I.L.Y. Spierts. 2014. Validation of a model to predict fish passage mortality in pumping stations. Can. J. Fish. Aquat. Sci. 71: 1910-1923. dx.doi.org/10.1139/cjfas-2014-0035. 